\title{
Effects of first feed intake time on growth performance, nutrient apparent metabolic rate and intestinal digestive enzyme activities in broilers
}

\author{
J. S. Wang' ${ }^{1}$, T. Y. Guo ${ }^{1}$, Y. X. Wang ${ }^{2}$, K. X. Li ${ }^{1}$, Q. Wang ${ }^{1}$, and X. A. Zhan ${ }^{1, *}$
}

\author{
* Corresponding Author: X. A. Zhan \\ Tel: +86-0571-88982127, Fax: +86-0571-88982650, \\ E-mail: xazan@zju.edu.cn \\ ' Feed Science Institute, College of Animal Science, \\ Zhejiang University, Hangzhou 310058, China \\ ${ }^{2}$ College of Animal Science and Technology, Zhejiang \\ A and F University, Linan 311300, China \\ ORCID \\ X. A. Zhan \\ https://orcid.org/0000-0001-6848-058X
}

Submitted Sept 2, 2017; Revised Oct 10, 2017; Accepted Nov 18, 2017
Objective: This experiment studied the effects of first feed intake time post-hatch on growth performance, nutrient apparent metabolic rate and intestinal digestive enzyme activities in broilers.

Methods: Two thousand five hundred and twenty LingNan Yellow broilers were randomly allotted to seven treatments with six replicates of 60 each. The only experimental factor was the first feed intake time which was 18, 24, 30, 36, 42, 48, and 54 hours after hatching. The whole experiment lasted for 21 days.

Results: During the whole period, the $30 \mathrm{~h}$ treatment had the best body weight and average daily gain $(\mathrm{p}<0.05)$, followed by the $24 \mathrm{~h}$ group performance optimization. Also, the $30 \mathrm{~h}$ group was observed to have the best apparent metabolic rate for ether extract $(\mathrm{p}<0.05)$ and crude protein $(\mathrm{p}<0.05)$ and the highest activities of amylase, lipase and trypsin in small intestine. And the $24 \mathrm{~h}$ group was second only to the $30 \mathrm{~h}$ group in terms of the above two measures.

Conclusion: These results indicated that the appropriate first feeding time of LingNan Yellow broilers was 24 to 30 hours after hatching.

Keywords: First Feed Intake Time; Growth Performance; Intestinal Digestive Enzyme; Apparent Metabolic Rate; Broiler

\section{INTRODUCTION}

The importance of post-hatch early-life nutrition to lifelong health and performance for broilers is beginning to be recognized. Chicks out of the shell usually can't leave the hatchery until most of the eggs have hatched under practical conditions. The delayed time from hatching to onset of feeding is quite common in the poultry industry due to the variation in hatching time of different eggs. It is disadvantageous for chicks to hatch early because of the prolonged fasting period and potential dehydration [1]. It is generally more than 48 hours until chicks reach the farm after a series of procedures such as vaccination, sex identification and transportation. Under practical conditions, many birds were delayed access to feed for 36 to $48 \mathrm{~h}$ after hatching, and body weight (BW) decreased during this time [2]. Delaying access to feed and water had been documented to increase weight loss [3], leading to poorly starting flocks with reduced weight gains. For the growth of poultry, yolk sacs were usually considered as the primary source of nutrition. During the fasting period, the residual yolk which was not used during fetal life could supply nutrients for chicks instead of feed. However, the nutrients in the residual yolk were insufficient to satisfy the requirements for both maintenance and growth in broiler chicks [4]. Through the changes in the composition and content of the yolk at $12 \mathrm{~h}$ and $130 \mathrm{~h}$ after hatching, it was found that the egg yolk 
nutrient was rapidly used and timely first feeding could promote the utilization of yolk [5]. Sklan and Noy indicated that the secretion of trypsin and amylase (AMS) into the intestine was triggered by feed intake [6]. The final BW of delayed feeding was lower than that of early feeding (EF), which meant providing EF supplements could improve BW [3]. Noy and Sklan speculated that in addition to enhanced gastrointestinal growth in birds with immediate access to feed, early feed consumption causes birds to begin to grow earlier and are thus "older" nutritionally [2].

Now broilers reach slaughter weight physiologically younger and younger, which means the first week post-hatch represents a larger proportion (20\%) in the whole life of broilers, so EF plays an important part in their growth. As researchers proposed, BW increases two to threefold during the first week [7-9].

There were some researches about first feeding time affecting growth performance from the perspective of intestinal enzymes. However, few studies were established to explore the apparent metabolic rate of nutrients and its relationship with intestinal enzymes. This paper explored nutrient apparent metabolic rate and intestinal digestive enzyme activities in broilers, the effects of different first feeding times on growth performance, and the optimal time for first feeding in broilers. And for the first time, this research viewed the effects of first feeding time on growth performance from the angle of apparent metabolic rate of nutrients in broilers.

\section{MATERIALS AND METHODS}

All procedures of the present study were coincided with the Chinese guidelines for animal welfare and were approved by the Zhejiang University Institutional Animal Care and Use Committee (Hangzhou, China).

\section{Bird management and experimental design}

Total of 2,520 LingNan Yellow male chicks were hatched from eggs produced by the same flock at a local hatchery (GuangDa Breeder Farm, JiaXing, China). Normal and healthy chicks were removed from the hatchery and weighed immediately, and randomly allotted to pens so that each pen of chicks had a similar initial weight and weight distribution. In order to minimize the variation of body weights caused by extended holding time in the hatchery, only birds emerging within four hours were taken for this study. Chicks were randomly assigned to seven treatments with six replicate pens of 60 broilers each (Xinxin Culture-Farm, JiaXing, China). All chicks were reared at floor pens with five-centimeter deep fresh wood shavings. During the experiment period, birds received $24 \mathrm{~h}$ light.

All groups received water ad libitum after hatching, but were fed only $18 \mathrm{~h}, 24 \mathrm{~h}, 30 \mathrm{~h}, 36 \mathrm{~h}, 42 \mathrm{~h}, 48 \mathrm{~h}$, and 54 h posthatch respectively. Times of post-hatch delayed in access to feed in this study were calculated from hatching time to first access to feed. Diets were formulated to meet nutrient requirements of broilers according to NRC [10]. Feeds were analyzed for crude protein $(\mathrm{CP})$ and ether extract (EE) according to the methods of GB/T6432-1994 and GB/T6433-2006. Ingredient composition and analyzed nutrients are presented in Table 1. Immunization and feeding management practices were similar to commercial broiler rearing.

\section{Sampling and measurements}

Mortality was checked and recorded daily by each replicate respectively, and then the date of death and BW of chicks were recorded. In addition, the following data were collected and calculated on day 1,7 , and 21 of the experimental period: BW, average daily gain (ADG), average daily feed intake (ADFI) and gain:feed. On day 4, 7 and 21, 4 chickens from each replicate respectively were randomly selected to be slaughtered for sampling after 12-h fasting (water offered ad libitum). The contents of duodenum, jejunum and ileum were collected, and frozen in liquid nitrogen immediately. All samples were stored at $-80^{\circ} \mathrm{C}$ prior to analysis. Digesta were weighed, homogenized with cold $0.86 \% \mathrm{NaCl}$, and aliquots of the homogenate taken for AMS, trypsin and lipase activity. The activities of AMS, trypsin, lipase and the concentration of protein were measured using kits (Nanjing Jiancheng Bioengineering Institute,

Table 1. Composition and nutrient content of the basal diet

\begin{tabular}{|c|c|}
\hline Items & $1-21 d$ \\
\hline \multicolumn{2}{|l|}{ Ingredients (\%) } \\
\hline Corn & 54.70 \\
\hline Wheat & 5.00 \\
\hline Soybean meal & 29.00 \\
\hline CGM & 6.00 \\
\hline Soybean oil & 1.00 \\
\hline $\mathrm{NaCl}$ & 0.30 \\
\hline CaHPO4 & 1.70 \\
\hline Limestone & 1.30 \\
\hline Premix ${ }^{1)}$ & 1.00 \\
\hline Total & 100.00 \\
\hline \multicolumn{2}{|c|}{ Nutrient levels ${ }^{2)}(\%)$} \\
\hline ME (kcal/kg) & 2,909 \\
\hline$C P$ & 20.96 \\
\hline Lys & 1.10 \\
\hline Met & 0.50 \\
\hline Met+Cys & 0.85 \\
\hline $\mathrm{Ca}$ & 0.99 \\
\hline TP & 0.66 \\
\hline
\end{tabular}

CGM, corn gluten meal; ME, metabolizable energy; $C P$, crude protein; TP, total phosphorus.

1) Supplied per kg of diet: vitamin $A, 9,600 \mathrm{IU}$; vitamin $D_{3}, 2,700 \mathrm{IU}$; vitamin $E_{\text {, }}$ 36 mg; vitamin $K_{3}, 3.0$ mg; vitamin $B_{1}, 3.0$ mg; vitamin $B_{2}, 10.5$ mg; vitamin $B_{6}$, $4.2 \mathrm{mg}$; vitamin $B_{12}, 0.03 \mathrm{mg}$; folic acid, $1.5 \mathrm{mg}$; nicotinamide, $60 \mathrm{mg}$; D-calcium pantothenate, $18 \mathrm{mg}$; biotin, $0.225 \mathrm{mg}$; choline chloride, 1,000 mg; Fe, $80 \mathrm{mg}$; $\mathrm{Cu}$, $8.0 \mathrm{mg}$; Mn, $80 \mathrm{mg} ; \mathrm{Zn}, 60$ mg; l, 0.35 mg; Se, $0.15 \mathrm{mg}$.

${ }^{2)} \mathrm{ME}$ is calculated value, other nutrient levels are measured values. 
Nanjing, China). The activities of AMS, trypsin and lipase were expressed as international units per gram of protein.

On 14 day, four chicks from each replicate were randomly selected to rear in the cages for metabolic experiment. After three days' adjustment period, a four-day formal experiment was conducted. For the determination of EE and CP metabolism, excreta from each replicate were collected at 09:00 am and 16:00 pm every day. After freeze-drying, extra samples were ground to pass through a 40-mesh screen and then analyzed for CP and EE according to GB/T6432-1994 and GB/ T6433-2006. And then the apparent metabolic rate of CP and EE were calculated.

\section{Statistical analysis}

Data was analyzed by using One-way analysis of variance procedure of SPSS 20.0 computer software. All the data were presented as the means of each treatment. The variability of data was expressed as standard error of the mean and a probability level of $\mathrm{p}<0.05$ was considered to be statistically significant.

\section{RESULTS}

Table 2 shows the effects of first feeding time on growth per-
Table 3. Effects of first feeding time on apparent metabolic rate of feed in broilers

\begin{tabular}{lcccccccc}
\hline \multirow{2}{*}{$\begin{array}{c}\text { Items } \\
(\%)\end{array}$} & \multicolumn{8}{c}{ Time of first feeding post-hatch $(\mathrm{h})$} \\
\cline { 2 - 8 } & $\mathbf{1 8}$ & $\mathbf{2 4}$ & $\mathbf{3 0}$ & $\mathbf{3 6}$ & $\mathbf{4 2}$ & $\mathbf{4 8}$ & $\mathbf{5 4}$ & SEM \\
\hline $\mathrm{CP}$ & $34.55^{\mathrm{b}}$ & $38.18^{\mathrm{a}}$ & $38.99^{\mathrm{a}}$ & $31.75^{\mathrm{c}}$ & $31.58^{\mathrm{c}}$ & $31.25^{\mathrm{c}}$ & $29.69^{\mathrm{d}}$ & 0.789 \\
$\mathrm{EE}$ & $84.58^{\mathrm{a}}$ & $84.27^{\mathrm{a}}$ & $84.58^{\mathrm{a}}$ & $84.34^{\mathrm{a}}$ & $83.91^{\mathrm{a}}$ & $82.67^{\mathrm{b}}$ & $79.78^{\mathrm{c}}$ & 0.368 \\
\hline
\end{tabular}

$\mathrm{SEM}$, standard error of the mean; $\mathrm{CP}$, crude protein; $\mathrm{EE}$, ether extract.

a-d Means $(n=6)$ within a row lacking a common superscript differ $(p<0.05)$.

formance and feed utilization of broilers. With the extension of the first feeding time, BW and ADG of 7 day increased, reaching the maximum at the $30 \mathrm{~h}$ group $(\mathrm{p}<0.05)$, followed by the $24 \mathrm{~h}$ group, but no significant difference between these two groups.

The effects of first feeding time on nutrient apparent metabolic rate of broilers is detailed in Table 3. The highest apparent metabolic rates of $\mathrm{CP}$ and $\mathrm{EE}$ were observed at the 24 and 30 group $(\mathrm{p}<0.05)$. And there was no significant difference between these two groups.

The effects of first feed intake time on intestinal enzyme activities of broilers at $4 \mathrm{~d}$ of age are given in Table 4 . The AMS, lipase and trypsin enzyme activities of the $30 \mathrm{~h}$ group in duodenum, jejunum and ileum were the highest $(\mathrm{p}<0.05)$, but

Table 2. Effects of first feeding time on growth performance in broilers

\begin{tabular}{|c|c|c|c|c|c|c|c|c|c|}
\hline \multirow{2}{*}{ Items } & \multirow{2}{*}{ Age (d) } & \multicolumn{8}{|c|}{ Time of first feeding post-hatch (h) } \\
\hline & & 18 & 24 & 30 & 36 & 42 & 48 & 54 & SEM \\
\hline \multirow[t]{3}{*}{$\mathrm{BW}(\mathrm{g})$} & 1 & 37.50 & 36.20 & 36.69 & 36.83 & 37.25 & 36.61 & 36.95 & 0.160 \\
\hline & 7 & $85.91^{b c}$ & $90.79^{\mathrm{ab}}$ & $96.05^{a}$ & $85.77^{\mathrm{bc}}$ & $83.70^{b c}$ & $83.11^{b c}$ & $79.92^{c}$ & 1.380 \\
\hline & 21 & 517 & 521 & 533 & 503 & 510 & 490 & 492 & 5.251 \\
\hline \multirow[t]{2}{*}{$A D G(g)$} & 7 & $6.92^{b c}$ & $7.80^{\mathrm{ab}}$ & $8.48^{\mathrm{a}}$ & $6.99^{b c}$ & $6.64^{b c}$ & $6.64^{b c}$ & $6.14^{c}$ & 0.211 \\
\hline & 21 & 22.85 & 23.06 & 23.62 & 22.19 & 22.49 & 22.59 & 21.65 & 0.231 \\
\hline ADFI (g) & 21 & 42.80 & 42.86 & 43.27 & 42.70 & 42.64 & 42.15 & 42.25 & 0.868 \\
\hline $\mathrm{G}: F(\mathrm{~g}: \mathrm{g})$ & 21 & 1.87 & 1.86 & 1.83 & 1.92 & 1.90 & 1.95 & 1.95 & 0.027 \\
\hline
\end{tabular}

SEM, standard error of the mean; BW, body weight; $A D G$, average daily gain; ADFI, average daily feed intake; G:F, gain:feed.

a-c Means $(n=6)$ within a row lacking a common superscript differ $(p<0.05)$.

Table 4. Effects of first feeding time on intestinal digestive enzyme activities of broilers on $\mathrm{d} 4$

\begin{tabular}{|c|c|c|c|c|c|c|c|c|c|}
\hline \multirow{2}{*}{ Items } & \multirow{2}{*}{$\begin{array}{c}\text { Enzyme } \\
\text { (U/g protein) }\end{array}$} & \multicolumn{8}{|c|}{ Time of first feeding post-hatch (h) } \\
\hline & & 18 & 24 & 30 & 36 & 42 & 48 & 54 & SEM \\
\hline \multirow[t]{3}{*}{ Duodenum } & AMS & $13.70^{c}$ & $48.86^{\mathrm{a}}$ & $45.65^{b}$ & $10.32^{d}$ & $9.09^{\text {de }}$ & $6.74^{e}$ & $6.50^{e}$ & 3.885 \\
\hline & Lipase & $303^{c}$ & $336^{b}$ & $367^{a}$ & $300^{\text {cd }}$ & $274^{\text {de }}$ & $271^{e}$ & $175^{f}$ & 12.87 \\
\hline & Trypsin & $94.25^{\mathrm{c}}$ & $99.79^{b}$ & $133^{\mathrm{a}}$ & $81.55^{d}$ & $59.99^{e}$ & $42.69^{f}$ & $34.99^{9}$ & 7.185 \\
\hline \multirow[t]{3}{*}{ Jejunum } & AMS & $31.79^{c}$ & $43.84^{b}$ & $52.66^{\mathrm{a}}$ & $22.75^{d}$ & $11.68^{\mathrm{e}}$ & $11.42^{\mathrm{e}}$ & $6.90^{f}$ & 3.643 \\
\hline & Lipase & $447^{b}$ & $473^{b}$ & $605^{\mathrm{a}}$ & $447^{b}$ & $402^{c}$ & $325^{\mathrm{e}}$ & $370^{d}$ & 18.72 \\
\hline & Trypsin & $221^{c}$ & $294^{b}$ & $397^{\mathrm{a}}$ & $203^{d}$ & $172^{\mathrm{e}}$ & $158^{e}$ & $111^{\dagger}$ & 19.94 \\
\hline \multirow[t]{3}{*}{ Ileum } & AMS & $54.45^{b}$ & $80.69^{a}$ & $57.11^{b}$ & $45.65^{c}$ & $42.08^{c}$ & $29.37^{d}$ & $25.12^{d}$ & 3.903 \\
\hline & Lipase & $626^{c}$ & $651^{b}$ & $742^{a}$ & $467^{d}$ & $418^{e}$ & $341^{\dagger}$ & $359^{f}$ & 32.68 \\
\hline & Trypsin & $344^{c}$ & $385^{b}$ & $405^{\mathrm{a}}$ & $326^{d}$ & $231^{f}$ & $245^{e}$ & $206^{g}$ & 16.36 \\
\hline
\end{tabular}

SEM, standard error of the mean; AMS, amylase.

${ }^{a-9}$ Means $(n=6)$ within a row lacking a common superscript differ $(p<0.05)$. 
AMS enzyme activities in duodenum and ileum was the best in the 24 hroup $(\mathrm{p}<0.05)$.

The results presented in Table 5 show the effects of first feeding time on intestinal enzyme activities of broilers on $7 \mathrm{~d}$ of age. The AMS, lipase and trypsin activities in duodenum, jejunum and ileum were the highest in the $30 \mathrm{~h}$ group $(\mathrm{p}<0.05)$, while the activities of trypsin in duodenum and activities of lipase in jejunum were the highest in the $24 \mathrm{~h}$ group $(\mathrm{p}<0.05)$.

Table 6 shows the effects of first feeding time on intestinal digestive enzyme activities of broilers on $21 \mathrm{~d}$ of age. On the whole, the AMS, lipase and trypsin activities in duodenum, jejunum and ileum were the highest in the $30 \mathrm{~h}$ group $(\mathrm{p}<0.05)$, and then the $24 \mathrm{~h}$ group was second only to the $30 \mathrm{~h}$ group in terms of these three enzyme activities.

\section{DISCUSSION}

Initiation of BW growth in neonate chicks was directly linked to feed availability [4]. Several reports had demonstrated that delay in feed intake after hatching adversely affected post-hatch growth performance of chicks [4,11-13]. It was common for chicks to lose weight during holding period mainly because of dehydration and yolk consumption [3,14]. Post-hatch holding of chicks before access to feed caused weight loss during holding time and depressed growth rate after access to feed [15]. And Careghi et al [15] demonstrated a positive curvilinear relationship between percentage of chick weight loss and holding time. The results of this study showed that the BW and ADG of broilers fed at $30 \mathrm{~h}$ post-hatch were both significantly higher than those of other groups at $7 \mathrm{~d}$ of age, and the smallest BW and ADG were observed at the $54 \mathrm{~h}$ group. In addition, there was no significant difference between the 24 $\mathrm{h}$ and $30 \mathrm{~h}$ group in terms of BW and ADG. This is in agreement with those findings which reported that chicks in the EF group had a greater BW than that of the early fasting group $[16,17]$. Bhanja et al $[18]$ conducted a more detailed grouping design of broiler feed times, and found that BW of each group feeding before 24 hours was greater than that of after 24 hours. Panda et al [19] observed that newborn chicks began to grow after 24 hours of ingestion, whereas fasting for too long led to a slowing of the gastrointestinal tract and immune system, and caused early weight loss [19]. Chicks just experiencing the shelling process have not yet resumed physical recovery. Under this circumstance, EF easily leads to excessive

Table 5. Effects of first feeding time on intestinal digestive enzyme activities of broilers on $7 \mathrm{~d}$ of age

\begin{tabular}{|c|c|c|c|c|c|c|c|c|c|}
\hline \multirow{2}{*}{ Items } & \multirow{2}{*}{$\begin{array}{c}\text { Enzyme } \\
\text { (U/g protein) }\end{array}$} & \multicolumn{8}{|c|}{ Time of first feeding post-hatch (h) } \\
\hline & & 18 & 24 & 30 & 36 & 42 & 48 & 54 & SEM \\
\hline \multirow[t]{3}{*}{ Duodenum } & AMS & $27.16^{c}$ & $31.09^{b}$ & $40.66^{a}$ & $22.80^{d}$ & $20.35^{d}$ & $21.32^{d c}$ & $17.95^{\mathrm{e}}$ & 1.642 \\
\hline & Lipase & $233.4^{\mathrm{b}}$ & $206.2^{c}$ & $242.6^{\mathrm{a}}$ & $162.3^{\mathrm{d}}$ & $37.95^{\mathrm{e}}$ & $20.56^{f}$ & $11.00^{\mathrm{g}}$ & 21.53 \\
\hline & Trypsin & $221^{c}$ & $776^{a}$ & $256^{b}$ & $178^{d}$ & $91.03^{\mathrm{e}}$ & $61.45^{f}$ & $37.97^{9}$ & 52.54 \\
\hline \multirow[t]{3}{*}{ Jejunum } & AMS & $26.37^{c}$ & $34.84^{b}$ & $56.53^{\mathrm{a}}$ & $24.24^{d}$ & $21.74^{\mathrm{e}}$ & $18.4^{\dagger}$ & $17.84^{\dagger}$ & 2.818 \\
\hline & Lipase & $629^{c}$ & $1,091^{\mathrm{a}}$ & $817^{b}$ & $547^{d}$ & $97.01^{\mathrm{e}}$ & $128^{e}$ & $68.90^{f}$ & 82.55 \\
\hline & Trypsin & $587^{c}$ & $862^{b}$ & $1,239^{a}$ & $585^{c}$ & $251^{d}$ & $129^{e}$ & $80.93^{e}$ & 87.28 \\
\hline \multirow[t]{3}{*}{ Ileum } & AMS & $29.53^{c}$ & $50.34^{b}$ & $59.37^{a}$ & $29.34^{c}$ & $25.91^{d}$ & $24.91^{\mathrm{e}}$ & $24.78^{e}$ & 2.904 \\
\hline & Lipase & $485^{c}$ & $1,040^{b}$ & $1,143^{\mathrm{a}}$ & $486^{c}$ & $132^{d}$ & $123^{d}$ & $33.73^{e}$ & 92.66 \\
\hline & Trypsin & $1,239^{b}$ & $1,255^{b}$ & $1,424^{\mathrm{a}}$ & $916^{d}$ & $1,016^{c}$ & $983^{c}$ & $639^{e}$ & 54.26 \\
\hline
\end{tabular}

SEM, standard error of the mean; AMS, amylase.

${ }^{a-9}$ Means $(n=6)$ within a row lacking a common superscript differ $(p<0.05)$.

Table 6. Effects of first feeding time on intestinal digestive enzyme activities of broilers on $21 \mathrm{~d}$ of age

\begin{tabular}{|c|c|c|c|c|c|c|c|c|c|}
\hline \multirow{2}{*}{ Items } & \multirow{2}{*}{$\begin{array}{c}\text { Enzyme } \\
\text { (U/g protein) }\end{array}$} & \multicolumn{8}{|c|}{ Time of first feeding post-hatch (h) } \\
\hline & & 18 & 24 & 30 & 36 & 42 & 48 & 54 & SEM \\
\hline \multirow[t]{3}{*}{ Duodenum } & AMS & $34.71^{\mathrm{a}}$ & $31.64^{\mathrm{ab}}$ & $52.44^{\mathrm{a}}$ & $23.02^{\mathrm{ab}}$ & $15.99^{\mathrm{ab}}$ & $11.82^{b}$ & $10.90^{\mathrm{b}}$ & 4.670 \\
\hline & Lipase & $299^{b c}$ & $363^{b}$ & $504^{\mathrm{a}}$ & $277^{b c}$ & $248^{\mathrm{bc}}$ & $174^{\text {cd }}$ & $149^{d}$ & 26.47 \\
\hline & Trypsin & $462^{b}$ & $362^{c}$ & $1,009^{\mathrm{a}}$ & $321^{c}$ & $256^{d}$ & $141^{\mathrm{e}}$ & $97.70^{e}$ & 63.51 \\
\hline \multirow[t]{3}{*}{ Jejunum } & AMS & $28.52^{\mathrm{ab}}$ & $27.52^{\mathrm{ab}}$ & $49.99^{\mathrm{a}}$ & $24.60^{\mathrm{ab}}$ & $10.49^{b}$ & $13.85^{b}$ & $6.00^{b}$ & 4.000 \\
\hline & Lipase & $284^{b}$ & $366^{b}$ & $809^{\mathrm{a}}$ & $167^{c}$ & $143^{c}$ & $92.57^{c}$ & $115^{c}$ & 53.09 \\
\hline & Trypsin & $995^{b}$ & $1,672^{\mathrm{a}}$ & $433^{c}$ & $252^{d}$ & $251^{d}$ & $108^{d}$ & $104^{d}$ & 121.9 \\
\hline \multirow[t]{3}{*}{ Ileum } & AMS & $30.57^{\mathrm{a}}$ & $34.84^{\mathrm{a}}$ & $36.62^{\mathrm{a}}$ & $25.12^{\mathrm{ab}}$ & $21.57^{\mathrm{ab}}$ & $20.78^{a b}$ & $11.09^{b}$ & 2.602 \\
\hline & Lipase & $1,750^{\mathrm{ab}}$ & $1,543^{\mathrm{ab}}$ & $2,248^{a}$ & $1,054^{\mathrm{bc}}$ & $1,031^{b c}$ & $435^{c}$ & $337^{c}$ & 170.7 \\
\hline & Trypsin & $685^{b}$ & $1,274^{\mathrm{a}}$ & $1,268^{\mathrm{a}}$ & $589^{c}$ & $444^{\mathrm{d}}$ & $384^{\text {de }}$ & $324^{e}$ & 83.61 \\
\hline
\end{tabular}

SEM, standard error of the mean; AMS, amylase.

${ }^{\text {a-e }}$ Means $(n=6)$ within a row lacking a common superscript differ $(p<0.05)$. 
fatigue and thus affects the body growth and development, so chicks starting to feed should have a suitable transition period, but the transition period should not be too long, which may be the reason why the $24 \mathrm{~h}$ and $30 \mathrm{~h}$ group in this experiment weighted higher than the other groups $(\mathrm{p}<0.05)$.

Yang et al [20] indicated that energy, EE and CP contents of the yolk decreased exponentially, and these nutrients of fed goslings were decreased significantly faster than those of fasted goslings. It was reported that holding chicks without feed decreased both the height and the area of small intestinal villi versus chicks allowed access to feed immediately [21]. The present study showed that the apparent metabolic rate of nutrient in broilers increased with the time of EF and the apparent metabolic rate of EE and CP were better in both $24 \mathrm{~h}$ and $30 \mathrm{~h}$ groups $(\mathrm{p}<0.05)$. The apparent metabolic rate of $\mathrm{EE}$ and $\mathrm{CP}$ were significantly lower in the $54 \mathrm{~h}$ group than in the other groups. It can be seen, EF helps the digestive metabolism of exogenous nutrients in chickens, which may be due to exogenous nutrients promoting the absorption of chicken yolk to strengthen intestinal development and thus enhance the digestion and metabolism of exogenous nutrients; for another possibility, exogenous nutrients may directly stimulate the development of the gastrointestinal tract and thus enhance its digestion and absorption capacity [22].

Chicks ingesting feed showed increases in total intestinal trypsin, AMS and lipase activities that were correlated with intestinal weights and BW [6]. Exogenous feed enhanced yolk utilization, stimulated intestinal peristalsis and triggered secretion of pancreatic enzymes enabling efficient digestion of nutrients after 4 days' post-access to feed [20]. From day 4, secretion of pancreatic enzymes per gram of feed intake changed little with age [23]. Research had also shown that digestive enzymes might be limited by adequate nutrient utilization posthatch in chicks and poults $[24,25]$ and that the concentrations of these digestive enzymes increased post-hatch. Throughout the trail, there was a difference $(\mathrm{p}<0.05)$ in the effect of different feeding time on the digestive enzyme activity of broiler intestinal chyme. With the increase of feeding time, the concentration of intestinal AMS increased, reaching the maximum at $30 \mathrm{~h}$ with the exception of a maximum of duodenum and ileum at $24 \mathrm{~h}$ on day 4 . And the $54 \mathrm{~h}$ group had the lowest concentration of AMS. The results of lipase and trypsin were similar to the result of AMS, almost all of them reached the maximum at $30 \mathrm{~h}$ group, followed by $24 \mathrm{~h}$ group. Besides, the results of 7 day and 21 day also suggested that $24 \mathrm{~h}$ group and $30 \mathrm{~h}$ group were the best two treatments. Our study indicated that there was an optimal feeding time of 24 to 30 hours which was different from that of Gonzales et al [13]. According to Gonzales et al [13], the maximum fasting period, which had no significant negative effect on final weight, was $24 \mathrm{~h}$ after the chicks were removed from the hatchers. This may be attributable to animal breeds, experimental conditions, setting criteria for opening time, animal physiology and other factors. In general, EF can improve the digestive enzyme activities of small intestine of broilers. Although the growth rate of lipase, AMS and trypsin were not the same, they were effective in promoting the improvement of digestive capacity in broilers. However, there was no systematic study on the mechanism of EF to promote digestive enzyme activity in broilers. Therefore, it was necessary to further explore the mechanism of $\mathrm{EF}$ to regulate the digestive enzyme activity of broilers from molecular or cytology.

It was possible, therefore, that the increase of digestive enzyme activity in the small intestine promoted the absorption and utilization of nutrients and increased the apparent metabolic rate of $\mathrm{EE}$ and $\mathrm{CP}$, leading to higher $\mathrm{ADG}, \mathrm{ADFI}$, and gain:feed. This may be the reason why the appropriate start feeding time, which was from 24 to 30 hours in this study, improved broiler performance.

In conclusion, this experiment indicated that it was not beneficial for newly hatched chicks to be exposed to exogenous feed as soon as possible. On the contrary, feeding untimely and prematurely could cause negative effects. It was recommended that, in our experiment, the appropriate time access to feed was from 24 to 30 hours post-hatch.

\section{CONFLICT OF INTEREST}

We certify that there is no conflict of interest with any financial organization regarding the material discussed in the manuscript.

\section{ACKNOWLEDGMENTS}

The financial support provided by China Agriculture Research System (project CARS-42-G19, Beijing, China) and Zhejiang Province Key S\&T (project 2013C02010, Hangzhou, China) are gratefully acknowledged.

\section{REFERENCES}

1. Tweed S. The hatch window. Cobb-Vantress Technical Focus 2005;2.

2. Noy Y, Sklan D. Yolk utilisation in the newly hatched poult. Br Poult Sci 1998;39:446-51.

3. Noy Y, Sklan D. Energy utilization in newly hatched chicks. Poult Sci 1999;78:1750-6.

4. Bigot K, Mignon-Grasteau S, Picard M, Tesseraud S. Effects of delayed feed intake on body, intestine, and muscle development in neonate broilers. Poult Sci 2003;88:781-8.

5. Wang Hemin, Huo Qiguang, Li Shaobiao, et al. Nutrient transfer in yolk sac of feeding chick. Xu Mu Shou Yi Xue Bao 1994;25:97-104.

6. Sklan D, Noy Y. Hydrolysis and absorption in the small intes- 
tines of posthatch chicks. Poult Sci 2000;79:1306-10.

7. Moss FP. The relationship between the dimensions of the fibres and the number of nuclei during normal growth of skeletal muscle in the domestic fowl. Am J Anat 1968;122:555-63.

8. Murakami H, Akiba Y, Horiguchi M. Growth and utilization of nutrients in newly-hatched chick with or without removal of residual yolk. Growth Dev Aging 1991;56:75-84.

9. Jin SH, Corless A, Sell JL. Digestive system development in post-hatch poultry. Worlds Poult Sci J 1998;54:335-45.

10. NRC. Nutrient requirements for poultry, 3rd ed. Washington, DC, USA: National Academy Press, 1994.

11. Becker WA. The storage of hat ching eggs and the posthatching body weight of chickens. Poult Sci 1960;39:588-90.

12. Pinchasov Y, Noy Y. Comparison of post-hatch holding time and subsequent early performance of broiler chicks and turkey poults. Br Poult Sci 1993;34:111-20.

13. Gonzales E, Kondo N, Saldanha ES, et al. Performance and physiological parameters of broiler chickens subjected to fasting on the neonatal period. Poult Sci 2003;82:1250-6.

14. Vieira SL, Moran ET. Effects of egg of origin and chick posthatch nutrition on broiler live performance and meat yields. Worlds Poult Sci J 1999;55:125-42.

15. Careghi C, Tona K, Onagbesan O, et al. The effects of the spread of hatch and interaction with delayed feed access after hatch on broiler performance until seven days of age. Poult Sci 2005; 84:1314-20.

16. Saki AA. Effect of post-hatch feeding on broiler performance. Int J Poult Sci 2005;4:4-6.
17. Husseiny OM, El-Wafa SA, El-Komy HMA. Influence of fasting or early feeding on broiler performance. Int J Poult Sci 2008;7: 263-71.

18. Bhanja SK, Devi CA, Panda AK, Sunder GS. Effect of post hatch feed deprivation on yolk-sac utilization and performance of young broiler chickens. Asian-Australas J Anim Sci 2009;22: 1174-9.

19. Panda AK, Shyam Sunder G, Rama Rao SV, Raju MVLN. Early nutrition enhances growth and speeds up gut development. World Poult 2006;22:15-6.

20. Yang HM, Wang ZY, Chen WL, et al. Effect of early feeding on the yolk nutrient utilization by goslings after hatching. Archiv für Geflügelkunde 2008;72:264-8.

21. Uni ZEHAVA, Ganot SAHAR, Sklan DAVID. Posthatch development of mucosal function in the broiler small intestine. Poult Sci 1998;77:75-82.

22. Juul-Madsen HR, Su G, Sørensen P. Influence of early or late start of first feeding on growth and immune phenotype of broilers. Br Poult Sci 2004;45:210-22.

23. Noy Y, Sklan D. Digestion and absorption in the young chick. Poult Sci 1995;74:366-73.

24. Nitsan Z, Dunnington EA, Siegel PB. Organ growth and digestive enzyme levels to fifteen days of age in lines of chickens differing in body weight. Poult Sci 1991;70:2040-8.

25. Sell JL, Angel CR, Piquer FJ, Mallarino EG, Al-Batshan HA. Developmental patterns of selected characteristics of the gastrointestinal tract of young turkeys. Poult Sci 1991;70:1200-5. 